STRUKTURNE KARAKTERISTIKE I POTENCIJALI RAZVOJA LJUDSKIH RESURSA VEZANO ZA PROCES PRIDRUŽIVANJA EU U SEVERNOM DELU AUTONOMNE POKRAJINE VOJVODINE (SUBOTICA, BAČKA TOPOLA, MALI IDJOŠ, KANJǏ̌A, SENTA, ADA, BEČEJ, С̌OKA)

\title{
THE STRUCTURAL CHARACTERISTICS AND POTENTIALS OF HUMAN RESOURCE DEVELOPMENT REGARDING TO EU ACCESSION IN THE NORTH REGION OF THE AUTONOMOUS PROVINCE OF VOJVODINA
}

PhD. Sándor Somogyi

András Ricz

PhD. Karolina Kajári

Dr. Irén Gabrity Molnár

PhD. Zoltán Lakner

Zoltán Takács

Anna Molnár

Društvo za Regionalne Nauke

Address: $\quad$ Matije Korvina 9, 24000 Subotica, Srbija

Phone: $\quad+38124670850$

E-mail: $\quad$ info@rtt.org.rs

Web: $\quad$ www.rtt.org.rs

Acknowledgement to:

- Centar za Strateško Ekonomska Istraživanja „Vojvodina CESS“ Novi Sad

- Austrijska Agencija za Razvoj (ADA) 


\title{
THE STRUCTURAL CHARACTERISTICS AND POTENTIALS OF HUMAN RESOURCE DEVELOPMENT REGARDING TO EU ACCESSION IN THE NORTH REGION OF THE AUTONOMOUS PROVINCE OF VOJVODINA
}

\author{
STRUKTURNE KARAKTERISTIKE I POTENCIJALI RAZVOJA \\ LJUDSKIH RESURSA VEZANO ZA PROCES PRIDRUŽIVANJA EU U \\ SEVERNOM DELU AUTONOMNE POKRAJINE VOJVODINE \\ (SUBOTICA, BAČKA TOPOLA, MALI IDJOŠ, KANJIŽA, SENTA, \\ ADA, BEČEJ, ČOKA)
}

Keywords: Economic development, human resources, quality of life, labor market, educational reform, forecast, scenarios, SWOT, creative economy

\begin{abstract}
:
In the course of the research our association observed the north region of Vojvodina, i.e. the questions of economic sevelopment and human resources with special focus on the territory of municipalities: Subotica, Bačka Topola, Mali Iđoš, Kanjiža, Senta, Ada, Čoka and Bečej.

Our final report presents all the findings of the research divided into four sections:

Section 1: Labour market of North Vojvodina in the light of employment - unemployment

Section 2: Necessity of educational reform

Section 3: Forecast of future trends in labour market of North Vojvodina and potential scenarios of economic development

Section 4: Final conclusions and proposals

The first section deals with questions of human capital and the quality of life, examines in details employers, employees, the unemployed and those looking for their first job, as well as the labour condition of the region.

The second part is about the lagging behind of the region's higher education, the question of adult education and further training, as well as searching for possible institutional solutions of the employment problems defined in the first section.

In the third section we intend to outline a realistic vision for the future over employment forecast based on time series, and defining possible scenarios of economic development. Moreover, here is a discussion about creative economy, the SWOT analysis of the observed region and formulated economic policy measures as well.

The last part enumerates the conclusions and proposals according to the order of the sections. For better clarity, bibliographic data are listed for every chapter at the end of this final report. In the appendices of this final report there is the research documentation, so the questionnaires, all the statistical data used in the course of the research together with the analytical tables of certain chapters that would not contribute to the readability of the text within the report.
\end{abstract}

Ključne reči: Privredni razvoj, humani kapital, kvalitet života,tržište radne snage, reforma obrazovanja, prognoze, scenarije, SWOT, kreativna ekonomija 


\section{Izvod:}

U ovim istraživanjima Drruštvo za Regionalne Nauke je obuhvatio Severnu Vojvodinu tj. opštine Subotica, B. Topola, Mali Idjoš, Kanjiža, Senta, Ada, Čoka i Bečej i fokusirao na problem ekonomskog razvoja i ljudskih resursa.

Završni izveštaj prikazuje rezultate istraživanja u četiri poglavlja:

1. Tržište radne snaage kroz prizmu zaposlenosti - nezaposlenosti.

2. Nužnost reforme obrazovanja

3. Prognoziranje daljih tendencija razvoja tržišta radne snage Severne Bačke, i moguće scenarije privrednog razvoja.

4. Zaključci i predlozi

Prvo poglavlje obuhvata probleme humanog kapitala, kvaliteta života, istraživanja poslodavaca, posloprimaca, nezaposlenih, posloprimaca koji traže prvo zaposlenje i stanje radne snage u regiji.

Drugo poglavlje obradjuje zapostavljenost regije u pogledu visokog školstva, obrazovanja odraslih i doškolovavanja, tražeći institucionalna rešenja za kadrovske probleme ustanovljene u prvom poglavlju.

Treće poglavlje se bavi prognozama zapošljavanja na osnovu vremenskih serija, projektovanjem scenarija budućeg privrednog razvoj i utvrdjivanja jasnije slike budućnosti. Pored toga obradjuje se problem kreativne ekonomije, SWOT analiza regije i mogućih instrumenata privrednog razvoja.

U četvrtom poglavlju su zaključci i predlozi, sredjeni prema prethodnim poglavljima i temama projekta.

U interesu jednostavnijeg korišćenja, literatura kao prilog projekta je sredjena po poglavljima i temama projekta.

U prilogu istraživačkog izveštaja je celokupna istraživačka dokumentacija, upitnici, statistički podaci i analitičke tabele po pojedinim temama, koje bi inače smanjile preglednost tekstulanog dela izveštaja.

Kulcsszavak: Gazdasági fejlődés, human tőke, életminőség, munkaerő piac, oktatási reform, prognózisok, forgatókönyvek, SWOT, kreatív gazdaság

\section{Kivonat:}

A kutatás keretében a Régionális Tudományi Társaság kutatói Vajdaság északi részét vizsgálta, különös tekintettel a gazdasági fejlődésre és az emberi erőforrásra, fókuszálva Szabadka, Topolya, Kishegyes, Kanizsa, Zenta, Ada, Csóka és Becse községekre.

A kutatási feladat zárójelentése a kutatási eredményeket négy fejezetre redukálva mutatja be:

1. Észak-Vajdaság munkaerőpiaca a munkavállalás - munkanélküliség szemszögéből

2. Az oktatási reform szükségessége

3. Észak-Vajdaság munkaerőpiaca jövőbeni tendenciáinak előrejelzése és a gazdasági fejlődés lehetséges forgatókönyvei

4. Következtetések és javaslatok

Az első fejezet magába foglalja a humántőke, életminőség, munkaadók munkavállalók, munkanélküliek, az első munkát keresők részletes vizsgálatait és a régió munkaerőlétét.

A második fejezet a régió felsőoktatási elmaradásával, felnőttképzéssel és továbbképzéssel foglalkozik, keresve a választ az első fejezetben megállapított káderproblémák megoldásának intézményesített lehetőségeire.

A harmadik fejezet a foglalkoztatás idősorokra alapozott prognózisaival és a gazdaságfejlesztés lehetséges forgatókönyvével foglalkozik egy reális jövőkép kimunkálása érdekében, de itt kap helyet a kreatív gazdaság taglalása valamint a SWOT elemzés és a megfogalmazható gazdasági eszköztár is.

A negyedik fejezetbe kerültek a fejezetek alpontjai szerint rendezett záradékok, majd javaslatok.

A könnyebb kezelhetőség érdekében a szakirodalom, mint melléklet pontonként van rendezve a könnyebb áttekinthetőség érdekében.

A jelentés mellékletét képezi a kutatási dokumentáció is, vagyis a felhasznált kérdőívek, kutatáshoz felhasznált statisztikai adatok és egyes pontok elemző táblázatai, amelyek nem növelnék a szöveges rész áttekinthetőségét. 


\section{Uvod}

Istraživači Regionalnog Naučnog Društva iz Subotice kontinuelno vrše istraživanja razvojnih problema severnog dela Vojvodine (Subotica, B. Topola, Mali Idjoš, Kanjiža, Senta, Ada, Beečej, Čoka). Istraživati problematiku ovog „nezvaničnog“ regija je značajno zbog niza karakteristika:

- U nacionalnom pogledu mešovito stanovništvo regije je izrazito tolerantno u medjusobnim odnosima i kooperativno, što predstavlja još neotkriveni razvojni potencijal kada je reč o postindustrijskom razvoju.

- Povećavanje značaja pograničnosti i blizine koridora X. omogućava da ovaj region bude kapija naše zemlje prema Evropi i kapija Evrope prema našoj zemlji, generirajući prihode, zapošljavanje sa razvojem logističkih, transportnih i drugih uslužnih delatnosti.

- U ranijem periodu ova regija je bila tretirana kao društveno -ekonomsko razvijeniji deo zemlje. Možemo se oslanjati na pozitivne tradicije, radne navike, tehničko - tehnološku kulturu $\mathrm{u}$ procesima daljeg razvoja, ali treba odlučiti da li nam je cilj oživeti raniju industrijsku, privrednu strukturu ili otići prema sofisticiranijoj strukturi ne samo u skladu sa lokalnim ciljevima nego i interesima pokrajine i Srbije kao celine. - Uslovi za proizvodnju hrane u regiji su diverzificirani. Uslovi su povoljni za razvoj proizvodnje žita, industrijskog bilja u Potisju, za proizvodnju groždja, voća, povrća na Subotičko - Horgoškoj pešćari, ali ne na poslednjem mestu ceo prostor ima povoljne uslove za razvoj stočarstva i prerade poljoprivrednih proizvoda. Proizvodni potencijali su ogromni posebno ako se ostvaruju uslovi za navodnjavanje.

- Istovremeno oseća se stagnacija, pa čak i zaostajanje u privrednom razvoju, zapošljavanju, što negativno utiče na društveno - ekonomske odnose u ovim opštinama. Postoji opasnost da to može biti generator daljeg zaostajanja ovog regiona.

\section{Sadržaj završnog izveštaja}

Uvod

Naša ranija istraživanja (objavljeni radovi, kratki sadržaji i najvažniji zaključci)

\section{Tržište rada Severne Vojvodine u svetlu zapošljavanja i nezaposlenosti}


1.1. Društveno - ekonomski specifičnosti humanog kapitala u Srbiji sa posebnim osvrtom na Severnu Vojvodinu - Takács Zoltán

1.2. Neke karakteristike kvaliteta života u Severnoj Vojvodini - Dr. Kajari Karolina, Dr. Somogyi Sándor

1.3. O nezaposlenosti i tržištu rada Severne Vojvodine - Dr. Gábrity Molnár Irén

1.4. Vrednovanje osobina, spremnosti, osposobljenosti i veština posloprimaca - Dr. Kajári Karolina, Dr. Somogyi Sándor

1.5. Dinamika nezaposlenosti prema školskoj spremi i opštinama u Severnoj Vojvodini izmedju 2000 i 2008. - Takács Zoltán, Molnár Anna

\section{Potrebe reforme obrazovanja}

2.1.Razmatranje uslova za formiranje univerziteta u regiji - Takács Zoltán, Dr. Gábrity Molnár Irén

2.2. Potrebe reforme obrazovanja odraslih - Takács Zoltán

\section{Predvidjanje budućih trendova zapošljavanja i scenarija ekonomskog razvoja}

3.1. Predvidjanje budućih trendova zapošljavanja u Severnoj Vojvodini - PhD Somogyi Sándor, PhD Lakner Zoltán, PhD Kajári Karolina

3.2. Mogući scenario ekonomskog razvoja Severne Vojvodine- PhD Somogyi Sándor, PhD Lakner Zoltán, PhD Kajári Karolina

3.3. Pouke vezano za kreativnu ekonomiju - PhD Somogyi Sándor, Ricz András

3.4. SWOT analiza Severne Vojvodine - PhD Gábrity Molnár Irén, PhD Lakner Zoltán

\section{Final conclusions and proposals}

\subsection{Zaključci}

4.2. Predlozi

Bibliográfia 


\section{Najvažniji zaključci}

\section{Tržište rada Severne Vojvodine u svetlu zapošljavanja i nezaposlenosti}

1. 1. Društveno - ekonomski specifičnosti humanog kapitala u Srbiji sa posebnim osvrtom na Severnu Vojvodinu

- Srbija je doživeo značajan pad (stručno, moralno i materijalno) kvaliteta i značaja humanog kapitala u procesima tranzicije.

- Na osnovu iskustava o regionalnim razlikama u Srbiji, Vojvodini i regionu ističe se suočavanje humanog kapitala sa novim izazovima i uslovima sticanja odgovarajućeg položaja u društvu.

- Regionalno autoorganizovanje kao oblik manifestacije humanog kapitala u Srbiji ne funkcioniše iako postoje dokazi da većinu problema nije moguće iz ,jednog centra“ rešavati.

- Za naše uslove - na Žalost - je karakteristično da pod pritiskom i centralizirajućim dejstvom vladajućih struktura je nastala regionalna i lokalna pasivizacija.

- U vakumu lokalne pasivnosti koja je nastala pod dejstvom centralizacije nezaposleni pokušavaju se prilagodjavati tržištu ad hoc. odlukama.

- Kompetentni, konkurentni humani kapital u regiji (kao u delu nacionalne privrede) može koncentrisati na ekonomski razvoj, konkurentnost, privlačenje investicija, produktivnost, ekonomski rast, efikasnost, na probleme prelaznog perioda i ubrzanje reformskih procesa i na konačni cilj, - na ambicije priključenja Evropskoj Uniji samo pod uslovima decentralizacije, postojanja regionalnog institucionalnog sistema, regulisanja izvora finansijskih izvora i jednakih uslova realizacije interesa.

- Naše institucije obrazovanja, zapošljavanja i budžetski organi teško se prilagodjavaju uslovima otvorenog tržišta i očekivanjima EU.

- Mogućnost efikasnog rešavanja problema ponašanja regionalnih i obrazovnih institucija je u prihvatanju strateških oblika ponašanja - odnosa prema zadacima.

- Region Severne Vojvodine posebno osetljivo pogadjaju nedostaci u mreži visokoškolskih ustanova. 
- U regionima Vojvodine, slično Severnoj Vojvodini aktivnosti istraživanja i razvoja nisu izrazito prisutni. Ono što funkcioniše od istraživačko - razvojnih aktivnosti, koncentrisano je u glavnom gradu Vojvodine.

\subsection{Neke karakteristike kvaliteta života u Severnoj Vojvodini}

Istraživanja koje se odnose na elemente - pokazatelje kvaliteta života su obuhvatale ispitivanja prema: tipovima naselja, uslovima stanovanja, snabdevenosti odredjenim sredstvima, prihodima, stavovima o soptvenom zdravstvenom stanju, korišćenju usluga bolnica, stavovima o porodičnom životu, stavovima - zadovoljstvu sa dosadašnjim tokom života, odnosu prema radnim obavezama, mišljenju o radu, korišćenju usluga zdravstvenih usluga, korišćenju dana bolovanja, zadovoljstvu sa životnim standardom, stavovima o sportu i rekreaciji, stavovima u vezi postojanja, nepostojanja strahova, stavovima o alkoholu, duvanu, drogi.

Zaključci koji su ustanovljeni potpuno su uskladu sa opštom situacijom i rangiranjem Srbije u medjunarodnim uporedjenjima na osnovu HDI indexa i pokazatelja zadovoljstva nezadovoljstva.

\subsection{O nezaposlenosti i tržištu rada Severne Vojvodine}

- Razlike u pogledu nezaposlenosti i fluktuacije po opštinama može se objasniti sa privredno - ekonomskom situacijom opština, i delom uspešnim ili neuspešnim procesima privatizacije.

- Ključni tereni privrednog razvoja i stvaranja uslova za veće zapošljavanje Severne Vojvodine su: Drugačije definisana poljoprivreda i preradjivačka industrija, razvoj prerade metala, električnih proizvoda, proizvodnje mašina, hemijskih proizvoda, laka industrija, odgovarajuća saobraćajna i uslužna infrastruktura, tranzitni saobraćaj robe, putnika i novca, logistički aktivnosti, turizam, ugostiteljstvo i sfera industrijskih usluga.

- Mogućnosti smanjenja nezaposlenosti treba tražiti prevashodno u sektoru malih, srednjih preduzeća i jačanju samozapošljavanja. Ukoliko regija neće moći poboljšati zapošljavanje može se računati sa ubrzanim eksodusom kvalifikovanih. 
- Istražujući razvijenost, mogućnosti razvoja može se utvrditi da Subotica, Bečej, Senta i Kanjiža se računaju u grupu razvijenih opština i u vojvodjaskim razmerama. Ada i B. Topola su u progresu, dok Čoka i Mali Idjoš spadaju u red najsiromašnijih opština

1.4. Vrednovanje osobina, spremnosti, osposobljenosti i veština posloprimaca

- Početna hipoteza istraživanja po kojem posloprimci i poslodavci slično vrednuju osobine, voljnosti i osposobljenosti navedene u upitniku, je samo delom potvrdjeno.

- Rangiranje osobina, voljnosti i osposoblenosti u funkciji školske spreme pokazuje da na radnim mestima koje zahtevaju višu školsku spremu se menja značaj pojedinih činioca. Posloprimci sa osnovnom školom su ubedjeni da voljnost za prekovremeni rad je najznačajnije za poslodavce. Kod posloprimaca sa višom školskom spremom na prvo mesto dolazi stručna kompetencija i znanje stranih jezika.

- Rangiranja od strane poslodavaca i posloprimaca dokazuje da u svakodnevnoj praksi postoji „kratak spoj“. Posloprimci u celini misle da poslodavci od njih očekuju voljnost za prekovremeni rad i korišćenje računara, a poslodavci tvrde da očekuju od posloprimaca stručne kompetencije i lojalnost.

1.5. Dinamika nezaposlenosti prema školskoj spremi i opštinama u Severnoj Vojvodini izmedju 2000 i 2008.

- Postepeno smanjivanje nezaposlenosti do 2008. godine može se objašnjavati sa (skoro potpunom) promenom celokupne društveno - ekonomske formacije, odnosno konsolidacijom procesa privatizacije.

- Vremenske serije za 2000 do 2008. i apsolutne cifre nezaposlenosti po godinama dokazuju da u Srbiji politika zapošljavanja je nedovoljno efikasna. Ne preduzimaju se mere - reforme obrazovanja i zapošljavanja, koje bi potpomagale veću privredno - društvenu valorizaciju radnog potencijala.

- Ispitivanje nezaposlenosti po opštinama je pokazala, da su problemi najizraženiji u Malom Idjošu, Čoki, Bečeju i Senti.

- Na osnovu ispitivanja odnosa tržišta radne snage i školovanosti se pokazalo da viša školska sprema stvara prednost u dobijanju radnog mesta. Nezaposlenost lica sa srednjim obrazovanjem je masovna, ali i oni lakše dolaze do radnog mesta nego lica bez kvalifikacije. 
- U odnosu na aktivno stanovništvo broj onih koji traže prvo radno mesto je povoljnije u regiji nego u Vojvodini i Srbiji. U ispitivanim opštinama početnici, pa tome adekvatno i žene lakše dolaze do svog prvog radnog mesta nego u Vojvodini i Srbiji.

\section{Potrebe reforme obrazovanja}

\subsection{Razmatranje uslova za formiranje univerziteta u regiji}

Lokalna i regionalna elita (akademski gradjani, državna birokratija i lica koja se izjašnjavaju u ime privrede) potkrepljuju potencijalnu regionalnu i društvenu potrebu osnivanja visokoškolskog centra - univerziteta sa sledećim argumentima:

- Regionalni multietnički univerzitet može da predstavlja adekvatno rešenje.

- Lokalna regionalna elita argumentira u korist pokrajinski osnovane institucije, umesto privatnih univerziteta.

- U slučaju postojanja društvenog konsenzusa ne bi postojao problem finansijskih izvora. Ova sredstva takodje mogu biti nadopunjena sa izvorima iz susedne Madjarske u okviru njihove manjinske politike kao i sredstva EU za multietničke programe.

- Multietnički univerzitet treba da se odlikuje intenzivnom Evropskom saradnjom.

- Razvoj visokog obrazovanja u regiji treba da bude i instrument regionalnog ekonomskog razvoja, stim da regija treba da uskladi svoje napore sa perspektivama i interesima države i nacije kao celine (da motiviše tesnu saradnju visokog obrazovanja i regionalnog razvoja, razvija koordinaciju medju granama i sektorima, inicira istraživanja, tehnološke i ekonomske inovacije i naučni transfer).

- Za osnivanje institucije nužno je raspolagati sa menadžerski nastrojenim, karizmatičnim, naučno priznatim kadrovima sa dobrim poslovnim i drugim vezama.

- Po pitanjima osnivanja multietničke institucije treba da se usaglase organi Vojvodjanskog Univerziteta, kao i državni organi Srbije i Vojvodine kao osnivači.

- Univerzitet Severne Vojvodine (Subotice) treba da opslužuje potrebe višenacionalne zajednice sa oko 500000 članova. Da bi to mogao realizirati potrebno je poštovati zahtev za otvorenošću prema potrebama regije kako u jezičkom, tako i u ekonomsko - razvojnom pogledu, bez dupliranja kapaciteta. 
- Multietnički univerzitet svoje zadatke treba da realizuje usaglašeno i u saradnji sa Univerzitetskim centrima u Novom Sadu i Segedinu. Istovremeno u tom trokutu treba da opravda svoje postojanje, elastičnošću i prilagodjavanjem ponude na tržištu znanja.

- U početnom periodu treba računati sa angažovanjem gostujućih profesora, podržavajući mobilnost, prolaznost kako nastavnika, tako i slušalaca a za kasnije potrebe organizovati posebne programe pripremanja nastavničkog kadra.

- Celishodno je pronaći takve naučno - stručne segmente za osnivanje novih fakulteta, koji će zadovoljiti društvene potrebe kako u regiji, tako i šire i koje se mogu pokriti nastavno - naučnim kadrom za potrebe akreditacije i uspešnog funkcionisanja.

- U Subotici tehničko- tehnološki i društveno - humanistički oblasti su pokrivene fakultetima u funkciji, medjutim za sada njihovi stavovi u vezi osnivanja novih jedinica nije jednoznačna.

\subsection{Potrebe reforme obrazovanja odraslih}

- Stručno obrazovanje i ,zahtev prema kompetencijama“ koje artikulira društvo, za sada ni delimično se ne preklapaju.

- Nacionalna služba zapošljavanja je jedina državna ustanova koja se redovno bavi (ponekad uz nedostatak vrhunske stručnosti) problemom stručnog osposobljavanja kao organizator, a najčešće i kao finansijer. $\mathrm{Na}$ žalost nastavni programi u većini slučajeva nisu u skladu sa stvarnim potrebama i rezultati nisu zadovoljavajući.

- Školsko obrazovanje odraslih ne udovoljava zahtevima sticanja stručne spreme koje su definisane od strane privrede, nezaposlenih i ostalih koji žele menjati profesiju.

- Visok nivo nezaposlenosti pre svega medju mladjim generacijama je stvorila „društveni sloj kursista“. Oni su svesni da se pohadjanje kurseva („lifelong learning“) pretvara na ovaj način u oblik života, ali u skladu sa materijalnim i drugim mogućnostima ipak koriste svaku priliku za sticanje novih saznanja.

- Ono što se realizuje u pogledu osposobljavanja i prekvalifikacije odraslih u organizaciji Nacionalne službe zapošljavanja i raznih drugih inicijativa nije od značajnijeg ekonomskog i socijalnog uticaja u našem društvu.

- Učešće stanovništva regije u procesima obrazovanja odraslih je izuzetno nizak.

- Nacionalne manjine u pogledu obrazovanja odraslih i sticanju kvalifikacija su u manje povoljnom položaju zbog nedovoljnog poznavanja državnog jezika. 
- U vojvodjanskim i regionalnim školskim institucijama nedostaje aktivno menadžiranje škola i praktično orijentisano obrazovanje - osposobljavanje slušaoca. Škole se mogu karakterisati sa prvenstvenom orijentacijom na popunjavanje kapaciteta.

- Podela rada izmedju škola unutar regiona je neadekvatna.

- Većina škola u regionu ne raspolaže jednostavnim i preglednim programom obrazovanja odraslih. Njihovi programi funkcionišu ad hoc. Vrlo često je reč samo o obrazovnom procesu redovnog školskog oblika, stručnog obrazovanja, eventualno prekvalifikacije, dopunskog osposobljavanja i specijalizaciji.

\section{Predvidjanje budućih trendova zapošljavanja i scenarija ekonomskog razvoja u}

\section{Severnoj Vojvodini}

3.1. Predvidjanje budućih trendova zapošljavanja u Severnoj Vojvodini

- Za regiju, Srbiju, Vojvodinu i svaku teritorijalnu jedinicu - opštinu regiona izradjena je prognoza zapošljavanja ARIMA modelom. Vrednosti $\mathrm{R}^{2}$ su iznad 0.95 izuzev za region. U principu prognoze se mogu smatrati dobrim na osnovu ovog pokazatelja.

- Prognoza povećanja zaposlenosti za Suboticu i Sentu prelazi 10\% za pet narednih godina, dok u ostalim opštinama, regionu, Vojvodini i Srbiji ostaje ispod 10\%.

- Prognostizirano povećanje za Čoku je izuzetno visoko, ali interval konfidencije nismo ni izračunali, jer donja granica pokazuje negativne (nelogične) vrednosti. Zbog toga prognoza za Čoku ne udovoljava kriteriju pouzdanosti i nije za korišćenje.

- Uporedjenje prognostiziranog nivoa zapošljavanja za 2015 sa nivoom zapošljavanja u ranijim godinama pokazuje da će Srbija tada postići nivo zaposlenosti iz 2002, Vojvodina iz 2001 - 2002, a regija će dostići nivo iz 2004 - 2005.

- Pojedine opštine, gradovi će dostići sledeće nivoe zapošljavanja: Subotica će dostići nivo iz 1994, Topola će dostići nivo iz 2009, Mali Idjoš će dostići nivo iz 2004 2005., Kanjiža će dostići nivo iz 2003, Čoka će dostići nivoiz 2004 - 2005, Senta će dostići nivo iz 1998, Ada će dostići nivo iz 2005 -2006 a Bečej će biti na nivou 2010.

- Prognostizirani nivoi zapošljavanja, odnosno godišnji rast zapošljavanja od 2 - 3 \% je u skladu sa scenarijom privrednog rasta, odnosno sa stagniranjem. 
3.2. Mogući scenario ekonomskog razvoja Severne Vojvodine

Treba istaći da nisu utvrdjeni u procesu računarskog generiraranja scenarija optimistički ili dominantni privredni procesi. Može se pretpostaviti da će veći broj procesa biti u funkciji paralelno. Sa analizom mogućih kombinacija procesa došlo se do sledećih zaključaka:

- Takve kombinacije procesa u kojima će agrar igrati izvesnu ulogu imaju zajedničku verovatnoću od 0. 428. Procesi u kojima je prisutna i stagnacija imaju verovatnoću od 0.357 a kombinacije procesa sa sektorom MSP imaju zajedničku verovatnoću od 0.16 .

- Na osnovu takvih rezultata prihvaćeno da je najveća verovatnoća realizacije takvog scenarija privrednog razvoja u kojem je uloga agrara istaknuta, uloga MSP umerena i prisutna je izrazita stagnacija.

- Polazeći od stava po kojem analiza optimističkih scenarija je suvišna, jer može dovesti do pasivnosti, prihvaćena je da analiza ovakvog pesimističkog scenarija.

- Ovakav scenario u svojoj suštini označuje da u ovom regionu ne postoji zadovoljavajući nivo endogenih snaga a da bude motor razvoja. Nezamislivo je da agrar, mala i srednja preduzeća ostvaruju takav nivo akumulacije, koje bi bilo dovoljno da generira strukturalne promene i razvoj.

- Jedini put promena i stvaranja razvojnih potencijala je u smanjenju izdvajanja u korist državnih prihoda i povećanje privlačnosti za kapital sa strane. Samo kapital sa strane može generirati razvoj proizvodnih potencijala, kapaciteta za uslužne delatnosti, logistiku i transport koje mogu za sobom povući razvoj malih i srednjih preduzeća i da generiraju intenzivnije zapošljavanje van poljoprivrede.

- Mogućnosti agrarnog sektora se zasnivaju na povoljnim klimatskim i drugim prirodnim uslovima. Probleme razvoja poljoprivredne proizvodnje treba posmatrati u zajedništvu sa preradjivačkom i prehranbenom industrijom.

- Bez obzira na nisku akumulativnost uloga poljoprivrede nemože biti zanemarena, jer je ona vezana za datu prirodnu lokaciju i socijalna sigurnost jednog dela stanovništva je u direktnoj zavisnosti od poljoprivrednih kapaciteta.

- U svakom slučaju agrarni sektor treba osloboditi viška radne snage i istovremeno sa mogućnostima diverzifikacije, kao što su bioproizvodnja, ruralni turizam, proizvodnja bioenergije, proizvodnja lekovitih, aromatičnih biljaka i mirodjija, 
proizvodnja voća, groždja, povrća, stočarskih proizvoda u zajedništvu sa prehrambenom industrijom treba tražiti mogućnosti proboja na tržište.

- Otkrivanje i iskorišćavanje tržišnih mogućosti ne treba tražiti u plasmanu - prometu sirovina nego u proizvodnji i plasmanu visoko valorizovanih gotovih proizvoda potrošnih dobara.

3.3. Pouke vezano za kreativnu ekonomiju

- Veoma je značajno proširiti pojam kreativne ekonomije i na znanjem intenzivne privredne grane. Takav pristup nama manje razvijenim zemljama više odgovara, jer sa razvojem i prestruktuiranjem privrede treba postići onaj nivo, koje omogućava ulazak u postindustrijalni period razvoja, što će povući za sobom i razvoj kreativne privrede.

- Analize pokazuju - na žalost - da naša konkurentnost u svetu biznisa i inovativnost daleko zaostaju za drugim okolnim zemljama, izuzev Bosne i Hercegovine.

- Ne raspolažemo ni adekvatnim menadžerskim slojem za zadatke koje nam diktira svetski razvoj i svetsko tržište. Prema našim istraživanjima naši menedžeri ne poznaju i veoma različito vrednuju one menedžerske metode koje su dobro poznate i isprobane $\mathrm{u}$ drugim delovima sveta.

- Malo imamo preduzeća sa velikim medjunarodnim iskustvom, koje mogu pokazati primer, mogu širiti nove moderne metode, koje su već isprobane sa uspehom u drugim zemljama.

- Organizovanje inkubatorskih kuća i klastera pružaju šanse i usluge koje inače nedostaju svim onim preduzetnicima, koji imaju zrele ideje, ali bez odgovarajuće pomoći nemogu realizirati.

- Ističe se značaj pravnog garantovanja i podržavanja inovatora u postizanju i realizaciji novih naprednih rešenja.

\section{Predlozi}

\section{Društveno - ekonomski specifičnosti humanog kapitala u Srbiji sa posebnim} osvrtom na Severnu Vojvodinu 
- U interesu ostvarivanja uslova za razvoj humanog kapitala nužno je realizovati multisektoralno približavanje, usaglašavanje interesa i komunikaciju izmedju privrednih i državnih -administrativnih subjekata.

- Nužno je otvoriti prostor za regionalnu samoorganizaciju humanog kapitala u Srbiji, Vojvodini, s obzirom da je dokazano na nivou nacionalne privrede, da su mnogi problemi nerešivi iz jednog centra. Zadaci i donošenje odluka treba da je delegirano na niže nivoe a takodje treba preorijentisati i alokaciju sredstava.

- Treba stvoriti uslove da posloprimci imaju aktivan odnos prema zapošljavanju i da donose dobro zasnovane odluke umesto uobičajenih ad. hoc odluka, a u interesu prilagodjavanja očekivanjima tržištu rada.

- Treba ubrzati prilagodjavanje svih obrazovnih institucija, ureda za zapošljavanje i budžetskih institucija tržištu i očekivanjima EU.

- Treba ostvariti strateške forme, načine ponašanja u obrazovnim i regionalnim institucijama.

\section{Neke karakteristike kvaliteta života u Severnoj Vojvodini}

\section{Predlozi koje se odnose na merenje kvaliteta života}

- Srbija treba bezuslovno da se uključi (ako to u medjuvremenu nije učinjeno) u realizaciju zadataka grupe zemalja koje su se priključile inicijativi OECD i treba otpočeti sa uspostavljanjem Sistema indikatora za merenje društvenog razvoja (Indicators for Measuring Social Progress) za našu zemlju, koja će meriti pozitivne i negativne promene trougla privrede- društva i prirodne okoline.

- Treba vagati i prihvatiti predloge „Stiglitz komisije“ (koja je formirana i radi po inicijativi francuskog predsednika Sarkozy-a ) u vezi merenja pokazatelja privrednog, društvenog razvoja i stanja okoline.

- Medjunarodna rangiranja na osnovu HDI indexa i drugih pokazatelja treba i dalje pratiti, da bi imali jasnu sliku o poboljšavanju ili slabljenju naših pozicija u medjunarodnim uporedjenjima.

- Treba stvoriti svest kod donosioca političkih odluka, stručnjaka i ne na poslednjem mestu kod celog stanovništva o kompleksnosti problema pokazatelja stanja i promena u trouglu privreda, društvo i okolina, koje govore o netržišnim dimenzijama (eksternalijama) našeg života i bitno utiču na kvalitet našeg života. 
Treba stvoriti svest da je teška preglednost, teška merljivost ovih pokazatelja zahteva pojačanu pažnju i odgovornost ako želimo dalje razvijati kvalitet našeg života.

\section{Predlozi na osnovu rezultata i zaključaka iz istraživanja uz pomoć upitnika}

- Sadašnja struktura naselja može biti sačuvana (s obzirom na visoku snabdevenost komunalnom infrastrukturom) stim da se povežu odgovarajućom putnom mrežom koja će obezbediti mobilnost radno sposobnog stanovništva do radnih mesta.

- Snabdevenost stanovništva sa automobilima, mobilnim telefonima i internetom je takodje ispitivano i utvrdjeno je da je sadašnja situacija je zadovoljavajuća u datim ekonomskim uslovima i pod datim nivoom prihoda, jer podržavaju mobilnost.

- Opšte zdravstveno stanje stanovništva, učestalost korišćenja bolničkog lečenja na osnovu stavova ispitanih ne pokazuje negativnu sliku, ali mreža zdravstva treba da je pod stalnim razvojem zbog uspešnije preventive.

- Računajući sa većom privrednom dinamikom, pojačanom zauzetošću stanovništva u budućnosti treba podržavati radno sposobno stanovništvo sa odgovarajućim javnim službama, obdaništima, zabavištima, mrežom školstva i uslužnim delatnostima.

- Ukoliko želimo dobar kvakitet života, kreativno društvo, onda i na strani poslodavaca i posloprimaca treba prevazići da se rad svata samo kao faktor ostvarivanja prihoda za život i da se prihvati pristup po kojem rad je i mogućnost samoostvarivanja.

- Kada je reč o strahovima stanovništva, treba svatiti da je to povezano i sa uživanjem alkohola, duvana i droge, protiv kojih treba produžiti društvene akcije. Većina ispitanih, koji uživaju drogu to neće priznati, ali bez obzira na to treba i u tom domenu pojačati društvene akcije, pored kriminološkog tretmana.

- Treba ostvariti koncept „učećeg društva“ i proširiti proces učenja kako na poslodavde, tako i na posloprimce u interesu bolje harmonije i boljeg kvaliteta života.

\section{O nezaposlenosti i tržištu rada Severne Vojvodine}

- Za prevazilaženje zanemarene privredne strukture jedino moguće funkcionalno rešenje je definirati ekonomski model održivosti. 
- $\quad$ interesu privrednog razvoja i smanjenja nezaposlenosti treba imati u vidu razvoj sledećih infrastrukturnih elemenata: saobraćaja, izgradnje mreže puteva, autoputa, obnova teretnog železničkog saobraćaja, razvoj kombinovanih transportnih terminala, razvoj rečnog saobraćaja na Tisi, otvaranje industrijskih zona i njihov infrastrukturni razvoj, razvoj logističke infrastrukture, gasifikacija i ekonomisanje sa prirodnim resursima (izgradnja prečistača otpadnih voda i izgradnja zalivne infrastrukture).

- Podržavanje poljoprivrede i preradjivačke industrije sa obezbedjenjem kredita, horizontalno povezivanje poljoprivrednih proizvodjača, vertikalno povezivanje sa preradjivačkom industrijom, prometnim organizacijama, formiranjem istraživačko tehnoloških centara, privlačenjem stranog kapitala, izgradnjom potrebnih preradjivačkih kapaciteta, hladnjača, uvodjenjem modernih tehnologija za preradu povrća, voća, proizvodnju finalnih potrošnih dobara, proizvodnju bioproizvoda, povezivanjem proizvodjača hrane $\mathrm{u}$ klastere $\mathrm{i}$ uključenje $\mathrm{u}$ pokrete menadžiranja kvaliteta i bezbednosti hrane.

- U smanjenju nezaposlenosti ozbiljnu ulogu mogu odigrati uslužni delatnosti i turizam. Treba računati sa sledećim elementima: korišćenje termalne vode, zdravstveni, lovački, ribarski, tranzitni, eko i seoski turizam, izgradnja biciklističkih staza, hipodroma,uslužnih centara, informacionih tačaka. Takodje treba razviti marketing svih vidova turizma.

- Rrazvoj i prikazivanje regionalnog imidža, popularizacija rekreativnih i kulturnih aktivnosti, prezentacija regiona kao centra obrazovanja i univerzitetskog života i uključenje u medjunarodne pokrete mreža regiona i procesa koje takve veze omoćuju.

\section{Vrednovanje osobina, spremnosti, osposobljenosti i veština posloprimaca}

- Realizirati koncept „učećeg društva“ u interesu veće kompatibilnosti stavova i poslodavaca i posloprimaca o medjusobnim odnosima, pravima i obavezama.

\section{Dinamika nezaposlenosti prema školskoj spremi u opštinama izmedju 2000 i 2008}

Predlažemo preduzimanje mera kako na Vojvodjanskom, tako i na lokalnom nivou za potpomanje razvoja humanog kapitala i to po sledećem: 
- Korišćenjem pokrajinskih kompetencija, preko lokalnih struktura treba realizirati mere razvoja humanog kapitala.

- U okvirima konkretno postojeće, zakonom regulisane teritorijalne organizacije države treba računati sa strateškim planiranjem na nivou Vojvodine kao NUTS 2 regiona.

- Treba prevazići i mimoići dekoncentrisanu institucionalnu strukturu centralne vlasti, koja funkcioniše na nižim nivoima za realizaciju delegiranih uputstava, predloga iz ministarstava, koje ni do sada se nisu pokazala efikasnim.

\section{Potrebe reforme obrazovanja}

\section{Razmatranje uslova za formiranje univerziteta u regiji}

- Neophodno je postići sporazum izmedju nadležnih organa regije i otpočeti sa osnivanjem univerziteta - centra znanja za zadovoljavanje potreba regije, jer je neodrživo stanje po kojem u Vojvodini postoji samo jedan univerzitet na oko 2 miliona stanovnika što je neuporedivo sa drugim delovima Srbije.

- Rešenje treba tražiti u kapacitetima postojećih fakulteta, ali treba računati i sa kapacitetima privatnih fakulteta.

- Vezano za univerzitet i na fakultete treba promisliti i osnivanje istraživačkih kapaciteta a u skladu sa stvarnim potrebama privrede.

- Takodje treba računati i sa decentraliziranim smeštajem pojedinih kapaciteta, računajući sa uslovima i ambicijama većih gradova.

\section{Potrebe reforme obrazovanja odraslih}

- Treba računati sa formiranjem mesnog institucionalnog sistema za obrazovanje i usavršavanje kadrova i obrazovanje odraslih. Treba odrediti organizacione okvire realizacije zadataka, jer samo na lokalnom nivou je moguće sagledati zahteve tržišta i sačiniti adekvatne obrazovne programe.

- Institucionalnom sistemu i organizacionim okvirima treba prilagoditi i finansiranje, ali svakako treba uzeti u obzir ne samo brojčane pokazatelje obuhvaćenih takvim sistemom, nego i kvalitet obrazovnog procesa, troškovnu efikasnost i mogućnost zapošljavanja slušalaca. 
- Treba uvesti instituciju učeničkih ugovora a u interesu povećavanja zainteresovanosti poslodavaca za kvalitetno funkcionisanje celog sistema dopunskog osposobljavanja kadrova.

- U interesu adekvatnog spoja teorije i prakse treba razviti odgovarajuću metodološku - pedagošku i inovacionu kulturu.

- Obavezno treba da usledi izrada instrumentarija aktivne, regionalne politike i strategije zapošljavanja u kojem će se definisati dugoročni ciljevi i institucionalna regulisanost obrazovanja odraslih.

\section{Prognoza zapošljavanja i scenarij privrednog razvoja}

Analize prikazane u I. Poglavlju, prognoze zapošljavanja i mogući scenarij ekonomskog razvoja pretpostavlja da Srbija, Vojvodina i opštine regije naprave hitne korake za sprečavanje stagnacije tj. daljeg zaostajanja regije:

- Treba smanjiti centralizaciju izdvanja a u interesu bolje finansijske snabdevenosti regije za razvojne potrebe.

- Treba povećavati regionalnu privlačnost za kapital sa strane.

- U procesima investiranja treba tražiti ravnotežu izmedju ulaganja u akumulativne kapacitete koje udovoljavaju i medjunarodnim merilima ekonomije veličine i takozvanim malim i srednjim preduzećima, koje se odlikuju višim nivoom radne intenzivnosti i zapošljavanja.

- Prehrambenoj industriji i poljoprivredi to jest proizvodnji hrane pružiti pomoć u tržičnom proboju sa zajedničkim marketingom.

- Stvoriti odgovarajuće pravne osnove zadrugarstva.

- Poljoprivredu osloboditi od viška radne snage sa razvojem drugih sektora privrede.

- Treba sprečiti ostvarivanje prognoza suviše niskog povećanja zaposlenosti. Smatramo da treba minimum $2 \%$ privrednog razvoja a da bi se nešto pokrenula na tržištu rada. Prema tome za povećanje zaposlenosti od bar $4-5 \%$ godišnje u interesu smanjenja i izbegavanja socijalnih problema i eksodusa stanovništva treba postići privredni rast od preko $5-6 \%$ godišnje. 


\section{Pouke vezane za kreativnu ekonomiju}

- Za koncepciju razvoja kreativne ekonomije, kreativnog društva, kreativnog staleža i njegov uticaj na društveni i privredni razvoj treba stvoriti osnove prosperiteta i stvoriti uslove da sposobnost, tehnologija i tolerancija dodju do izražaja.

- Bezuslovno treba uložiti dalje napore u razvoj inkubatorskih kuća i klastera uzimajući u obzir i mogućnost uključenja u medjunarodne tokove na tom polju.

- Treba stvoriti odgovarajuće pravne osnove za sigurnost intelektualnih vlasništava i to bezuslovno garantirati u svim segmentima društva.

\section{RESUME}

In the course of the research titled The structural characteristics and potentials of human resource development regarding to $\mathrm{EU}$ accession in the north region of the Autonomous Province of Vojvodina our association observed the north region of Vojvodina, i.e. the questions of human resources with special focus on the territory of municipalities: Subotica, Bačka Topola, Mali Iđoš, Kanjiža, Senta, Ada,Čoka and Bečej. Our final report presents all the findings of the research divided into sections and chapters:

Introduction

Previous researches of the Regional Science Association on socioeconomic characteristics of human capital (Zoltán Takács)

\section{SECTION 1}

\section{Labour market of North Vojvodina in the light of employment - unemployment}

1.1. Socio-economic characteristics of human capital in Serbia with special regard to North Vojvodina (Zoltán Takács)

1.2. Some characteristics of the quality of life in North Vojvodina (PhD Karolina Kajári, PhD Sándor Somogyi)

1.3. Labour market situation in North Vojvodina (PhD Irén Gábrity Molnár)

1.4. Assessment of employee qualities, skills and abilities from the employers' and employees' standpoint (PhD Karolina Kajári, PhD Sándor Somogyi) 
1.5. Dynaics of the unemployed concerning their qualifications and municipalities in North Vojvodina between 2000-2008 (Zoltán Takács, Anna Csiszár Molnár)

\section{SECTION 2}

Necessity of educational reform

2.1. Higher education needs and requirements in North Vojvodina (Zoltán Takács, PhD Irén Gábrity Molnár)

2.2. Demand for adult education and further training in the region (Zoltán Takács)

\section{SECTION 3}

Forecast of future trends in labour market of North Vojvodina and potential scenarios of economic development

3.1. Forecast of future trends of employment in North Vojvodina (PhD Sándor Somogyi, PhD Zoltán Lakner, PhD Karolina Kajári)

3.2. Potential scenarios of economic development in North Vojvodina ( $\mathrm{PhD}$ Sándor Somogyi, PhD Zoltán Lakner, PhD Karolina Kajári)

3.3. Lessons concerning creative economy ( $\mathrm{PhD}$ Sándor Somogyi, András Ricz)

3.4. SWOT analysis of North Vojvodina (PhD Irén Gábrity Molnár, PhD Zoltán Lakner)

\section{SECTION 4}

Final conclusions and proposals

\subsection{Final conclusions}

4.2. Proposals for policy makers

Bibliography

\section{REZIMÉ}

A humánerőforrás-fejlesztés szerkezeti jellemzői és potenciálja Vajdaság Autonóm Tartomány északi régiójában az EU csatlakozás tükrében (Szabadka, Topolya, 
Kishegyes, Kanizsa, Zenta, Ada,Csóka és Becse eredményeit tartalmazó kutatási jelentést összes eredményeivel négy részben és a következő fejezetek tartalmazzák.

\section{Bevezető}

Regionális Tudományi Társaság korábbi kutatásai a humántőke társadalom-gazdasági jellemzői kapcsán (Takács Zoltán)

\section{RÉSZ}

\section{Észak - Vajdaság munkaerőpiaca a munkavállalás - munkanélküliség szemszögéből}

1.1. A humántőke társadalom-gazdasági sajátosságai Szerbiában különös tekintettel Észak Vajdaságra (Takács Zoltán)

1.2. Az életminőség néhány jellemzője Észak- Vajdaságban (PhD. Kajári Karolina, PhD. Somogyi Sándor)

1.3. Munkaerőpiaci helyzetkép Észak - Vajdaságban (Dr. Gábrity Molnár Irén)

1.4. Munkavállalói tulajdonságok, készségek és képességek értékelése munkavállalói és munkaadói szempontból (PhD. Kajári Karolina, PhD. Somogyi Sándor)

1.5. A munkanélküliek dinamikája iskolai végzettség és községek szerint Észak - Vajdaságban 2000 - 2008 között (Takács Zoltán, Csiszár Molnár Anna)

\section{RÉSZ}

\section{Az oktatási reform szükségessége}

2.1. Az észak-vajdasági régió felsőoktatási szükségletei, igényei (Takács Zoltán, DR. Gábrity Molnár Irén)

2.2. A régió felnőttoktatási és felnőttképzési igényei (Takács Zoltán)

\section{RÉSZ}

Észak - Vajdaság munkaerôpiaca jövőbeni tendenciáinak előrejelzése és a gazdasági fejlődés lehetséges forgatókönyvei

3.1. A munkavállalás jövőbeni tendenciáinak elörejelzése Észak - Vajdaságban (PhD. Somogyi Sándor, PhD. Lakner Zoltán, PhD. Kajári Karolina)

3.2.Észak - Vajdaság gazdasági fejlődésének lehetséges forgatókönyvei (PhD. Somogyi Sándor, PhD. Lakner zoltán, PhD. Kajári Karolina)

3.3. A kreatív gazdasággal kapcsolatos tanulságok (PhD. Somogyi Sándor, Ricz andrás)

3.4. Észak - Vajdaság SWOT elemzése (Dr. Gábrity Molnár Irén, PhD. Lakner Zoltán)

\section{RÉSZ}


DETUROPE - THE CENTRAL EUROPEAN JOURNAL OF REGIONAL DEVELOPMENT AND TOURISM Vol.3 Issue 2011

Következtetések

Javaslatok

Bibliográfia 